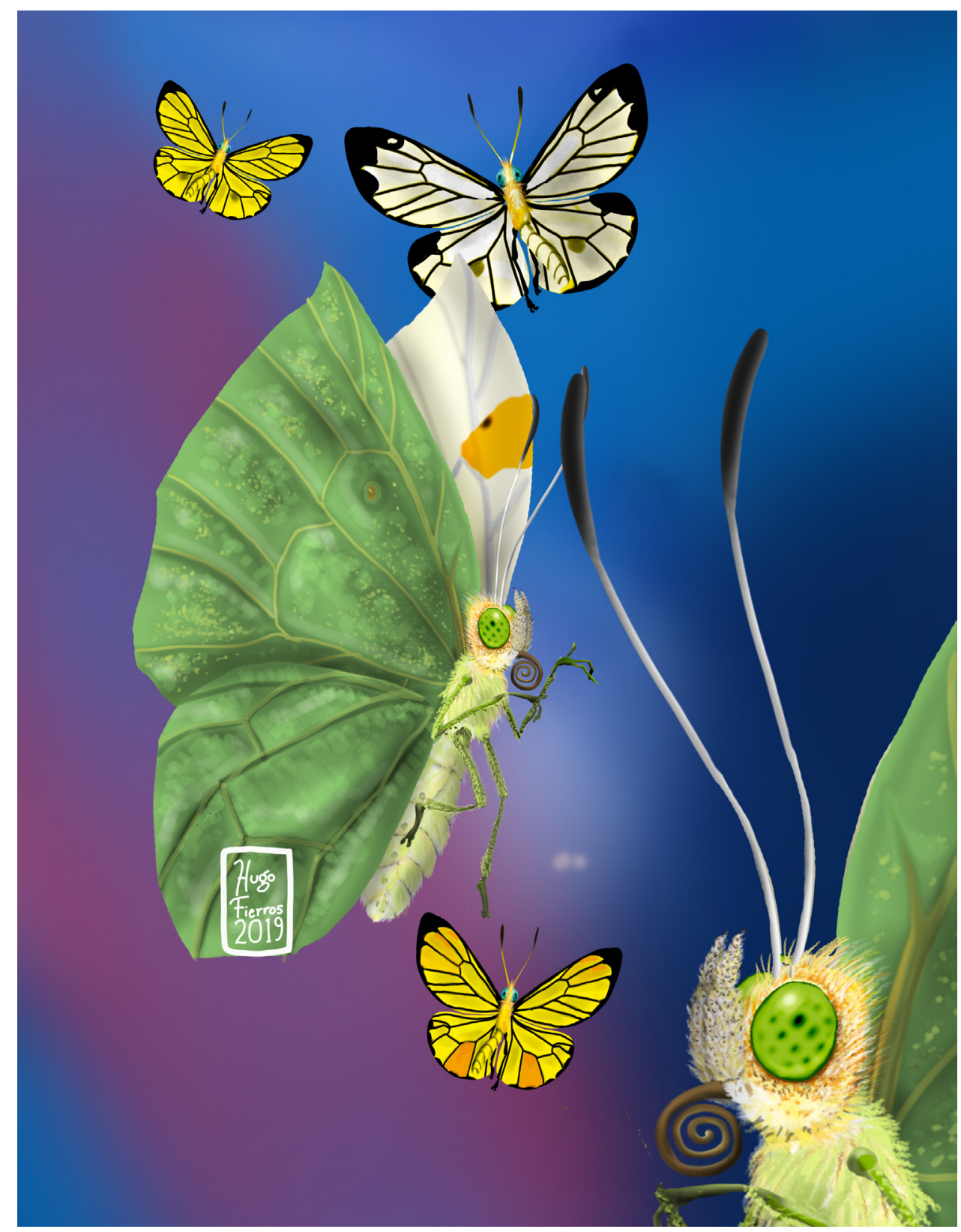

Dugesiana, Año 26, No. 2, julio 2019-diciembre 2019 (segundo semestre de 2019), es una publicación semestral, editada por la Universidad de Guadalajara, a través del Centro de Estudios en Zoología, por el Centro Universitario de Ciencias Biológicas y Agropecuarias. Camino Ramón Padilla Sánchez \# 2100, Nextipac, Zapopan, Jalisco, Tel. 37771150 ext. 33218, http://148.202.248.171/dugesiana/index.php/DUG/index, glenusmx@gmail.com. Editor responsable: José Luis Navarrete Heredia. Reserva de Derechos al Uso Exclusivo 04-2009-062310115100203, ISSN: 2007-9133, otorgados por el Instituto Nacional del Derecho de Autor. Responsable de la última actualización de este número: José Luis Navarrete Heredia, Editor y Ana Laura González-Hernández, Asistente Editorial. Fecha de la última modificación 25 de julio 2019, con un tiraje de un ejemplar.

Las opiniones expresadas por los autores no necesariamente reflejan la postura del editor de la publicación.

Queda estrictamente prohibida la reproducción total o parcial de los contenidos e imágenes de la publicación sin previa autorización de la Universidad de Guadalajara. 
Nota científica

\title{
Gregarious behavior of two species of Cassidinae (Coleoptera: Chrysomelidae) in Mexico
}

\section{Comportamiento gregario de dos especies de Cassidinae (Coleoptera: Chrysomelidae) en México}

\author{
Fatima Magdalena Sandoval-Becerraํㅜ, Geovanni M. Rodríguez-Mirón ${ }^{2}$, José Luis Barragán-Ramírez ${ }^{3}$ \& Sara \\ López-Pérez ${ }^{2 *}$ \\ ${ }^{1}$ División de Estudios de Posgrado e Investigación. Tecnológico Nacional de México, Instituto Tecnológico de Cd. \\ Victoria, Boulevard Emilio Portes Gil No.1301, C.P. 87010. Ciudad Victoria, Tamaulipas, México. ${ }^{2}$ Colección \\ Coleopterológica, Museo de Zoología, Facultad de Estudios Superiores Zaragoza, Universidad Nacional Autónoma \\ de México, Av. Guelatao 66, Ejército de Oriente, Iztapalapa, C.P. 09230, Cd. Mx., México. ${ }^{3}$ Centro de Estudios en \\ Zoología, Centro Universitario de Ciencias Biológicas y Agropecuarias, Universidad de Guadalajara, C.P. 134, \\ 45100, Zapopan, Jalisco, México. *Corresponding author: slopez.p@hotmail.com
}

Aggregation refers to a spatial distribution pattern, where individuals are grouped (Patil and Stiteler 1974). In many cases, this behavior is maintained by the interaction with pheromones. However, insects also use visual cues and signals to regulate aggregation (Bengtsson 2008). For insects, this conduct can have a direct relation with fitness; it can reduce the probability of predation and decrease body water loss (Flowers 1991, Bengtsson 2008, Boulay et al. 2019). In a mixed-species group, the advantages could be attributed to the direct increase in group size (Boulay et al. 2019). When different species gather even more individuals can be aggregated and more benefits can be obtained when compared with monospecific groups, for example a better food assimilation or temperature regulation (larvae aggregations) (Boulay et al. 2019, Rivers et al. 2011). Also, this behavior can provide protection against environmental constraints, or foraging advantages (Weed 2010).

Aggregation has been registered for several families of beetles, including Chrysomelidae (Hodek, 2012), where some species of the subfamily Cassidinae (tortoise beetles) have been observed in aggregations of mixed-species during the dry season (Flowers 1991). Herein, we report for the first time the aggregation behavior for the tortoise beetles Physonota humilis Boheman, 1856 and Ogdoecosta epilachnoides (Champion, 1893). Both species were found intermixed with other beetle species. Small aggregations of Physonota humilis (Fig. 1a, b) have been observed during the rainy season of 2014 and the dry season of 2018 in an oak forest in the locality of Mesa del Ocote, Sierra del Travesaño, in Chapala, Jalisco (2 450 m) (Fig. 1c). These aggregations were found beneath the bark of dead oak (Quercus sp.), mixed with two species of Epilachna Chevrolat (Coccinellidae) (Fig. 1d).

A dense aggregation of Ogdoecosta epilachnoides (Fig. 2a) was observed in a dry forest of Ajijic, El Tapalo in Chapala, Jalisco $(1,650 \mathrm{~m})$, where more than 200 specimens of $O$. epilachnoides were observed beneath the bark of a tree trunk (Fig. 2b). In the same locality a second aggregation of more than 50 specimens of $O$. epilachnoides was observed in the epiphyte, Tillandsia recurvata (L.) (Fig. 2c). Also, some individuals of $O$. epilachnoides were found in adjacent vegetation. These aggregations were observed close to a stream during visits in the dry and rain season of years 2014 and 2018.

Another aggregation of $O$. epilachnoides was found in October of 2011 in an oak forest, in the locality of Zacoalpan, Mexico (2,500 m) (Fig. 2d). This aggregation was found in a different species of Bromeliaceae. It was formed by more than 200 individuals mixed with two specimens of Ogdoecosta biannularis (Boheman, 1854). Also, many elytra of $O$. epilachnoides were found in the same Bromeliaceae.

Although there are reports for Cassidinae aggregations, little is known about the factors that influence this behavior. According to Flowers (1991), the flat and expanded elytra and the shape of pronotal margins could be an advantage in exploiting transpired moisture during dry season. In the subfamily Cassidinae, the humidity and temperature are important factors that regulate their activity (SandovalBecerra et al. 2016). However, the aggregations reported herein are different, because $P$. humilis and $O$. epilachnoides have been observed beneath the bark of a tree during all the year, not only in dry season. Thus, the aggregation of these species could be interpreted as a defense mechanism. Also, the microclimatic conditions that these refuges offer to tortoise beetles may allow them conserve energy and water.

Additionally, bromeliads are an occasional place of concealment, but also its particular structure allows water storage. Terrestrial animals and insects use this water reservoir, since these epiphytes offer an apparently favorable microhabitat. This is especially notable during dry seasons, when bromeliads provide refuge of apparently 
higher humidity (Frank and Lounibos 2009). However, the aggregation of $O$. epilachnoides in Tillandsia recurvata was observed during all year. It seems that, in this particular case, the aggregations of this species are not for a moist refuge. Sometimes, aggregations might originate from an intrinsic tendency to join conspecifics and clump together, but also aggregations may decrease the risk of predation and parasitism (Honek et al. 2007).

\section{ACKNOWLEDGMENTS}

We would like to thank to Edmar Meléndez-Jaramillo for the taxonomic identification of Tillandsia recurvata (L.); likewise to Uriel Jeshua Sánchez-Reyes and Diego Fernando Rodríguez Peraza for some pictures of live beetles in situ. We also thank Carlos Balboa and two anonymous reviewers for their comments on the manuscript and English edition.

\section{LITERATURE CITED}

Bengtsson, J. 2008. Aggregation in Non-social Insects: An Evolutionary Analysis. SLU, Switzerland.

Boulay, J., C. Aubernon, G.D. Ruxton, V. Hédouin, J.L. Deneubourg and D., Charabidzé. 2019. Mixed species aggregations in arthropods. Insect Science, 26(1): 1-19.

Recibido: 26 de noviembre 2018

Aceptado: 25 de marzo 2019
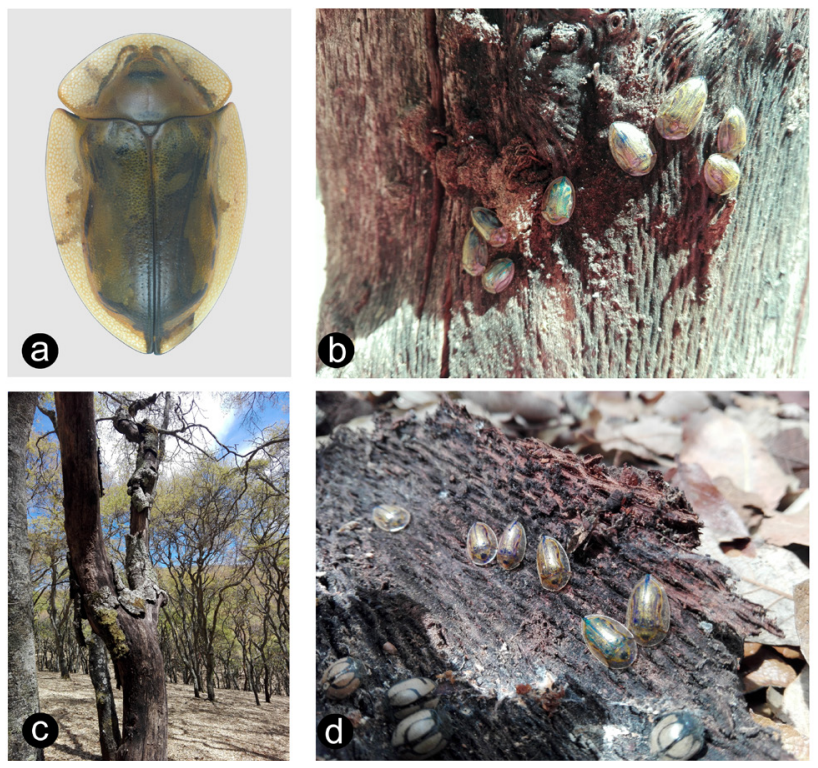

Figure. 1. Physonota humilis. a) Dorsal view; b) aggregation of $P$. humilis in Quercus sp.; c) Oak forest at Mesa del Ocote, Sierra del Travesaño, Chapala, Jalisco; d) P. humilis with two species of Epilachna.
Flowers, R.W. 1991. Aggregations of Cassidinae (Chrysomelidae) in Santa Rosa and Guanacaste National Parks, Costa Rica. Biotropica, 23(3): 308-310.

Frank, J.H. and L.P. Lounibos. 2009. Insects and allies associated with bromeliads: a review. Terrestrial Arthropod Reviews, 1(2): 125-153.

Hodek, I., 2012. Adult diapause in Coleoptera. Psyche, 2012: 1-10.

Honek, A., Z. Martinková and S. Pekár. 2007. Aggregation characteristics of three species of Coccinellidae (Coleoptera) at hibernation sites. European Journal of Entomology, 104(1): 51-56.

Patil, G.P. and W.M. Stiteler. 1974. Concepts of aggregation and their quantification: a critical review with some new results and applications. Researches on Population Ecology, 15(1): 238-254.

Rivers, D.B., C. Thompson and R. Brogan. 2011. Physiological trade-offs of forming maggot masses by necrophagous flies on vertebrate carrion. Bulletin of Entomological research, 101(5): 599-611.

Sandoval-Becerra, F.M., U.J. Sánchez-Reyes, S. NiñoMaldonado and J.V. Horta-Vega. 2016. Patrones de actividad de Cassidinae Gyllenhal, 1813 (Coleoptera: Chrysomelidae) en el Sendero Interpretativo El Tepalo, Chapala, Jalisco. Entomología Mexicana, 3: 488-494.

Weed, A.S. 2010. Benefits of larval group feeding by Chrysolina aurichalcea asclepiadis on Vincetoxicum: improved host location or feeding facilitation? Entomologia Experimentalis et Applicata, 137(3): 220228.
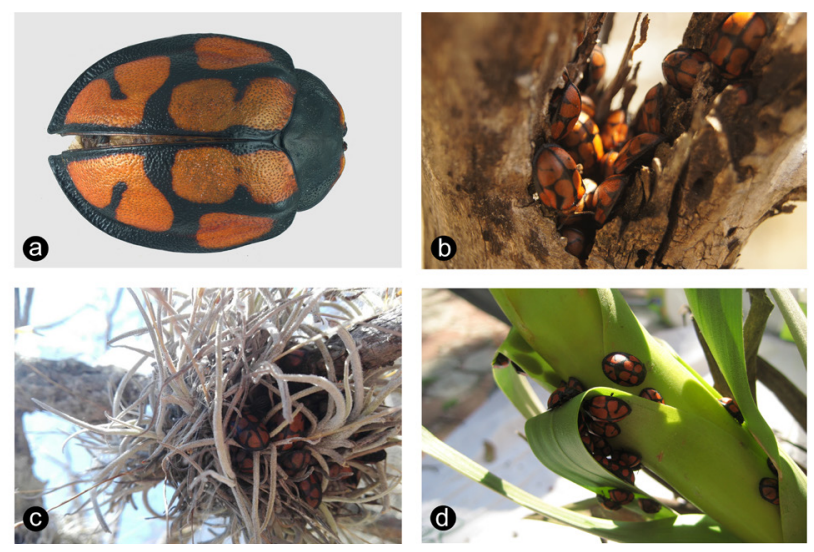

Figure. 2. Ogdoecosta epilachnoides. a) Dorsal view; b) aggregation under the bark of dead tree trunk (photo by Diego F. Rodríguez Peraza); c) aggregation in Tillandsia recurvata (photo by Uriel J. Sánchez-Reyes); d) aggregation in a different bromeliad. 